\title{
Slavery, slave trade and reparation movement in Africa
}

\section{Tunji Omotoso}

Department of History, Emmanuel Alayande College of Education, (formerly, Oyo State College of Education), Lanlate, Oyo State, Nigeria

\author{
Email address: \\ shootjohn2001@yahoo.com
}

\section{To cite this article:}

Tunji Omotoso. Slavery, Slave Trade and Reparation Movement in Africa. History Research. Vol. 2, No. 1, 2014, pp. 1-6. doi: 10.11648/j.history.20140201.11

\begin{abstract}
Slavery and slave trade, no doubt contributed to the underdevelopment of Africa. It was a phenomenon which demeaned Blackman's dignity and laid the foundation of racial inequality between Whiteman and black-skinned man. Slave trade aided the growth and development of the slave-holding nations and retarded the growth and development of Africa. Many scholars have challenged the relationship between Africa and the outside world, which according to them, altered the rate at which Africa's development was growing prior to slave trade, hence, the calls for reparations as a form of restitution for the injustice perpetrated by Christian Europe and Muslim Arabs who were beneficiaries of slave trade. This paper therefore examines slavery and slave trade with their effects on Africa and includes Arab World as co-culprit with Europe and therefore liable to pay reparations alongside with Europe to Africa. The work carefully examines reparation's Movements in Africa together with the arguments of anti-reparation advocates. Also, the paper take a review of examples of reparations paid in the past to victims of injustice which acted as a basis for several reparation calls in Africa in the 1990s. The work concludes by making suggestions on how best reparation idea should be championed which according to the writer, is a 'just course' that must be pursued to a logical conclusion.
\end{abstract}

Keywords: Africa, Slavery, Reparation, Underdevelopment

\section{Introduction}

Slavery is as old as humanity. Inikori submitted that slavery existed at one time or another in every society and went further that it is a reflection of the general tendency in all human societies for the strong to exploit the weak ${ }^{1}$.

Historically, every race has at one time or another sold its members into slavery. Slavery in a nutshell is the condition in which one person is the property of another while slave trade is the buying and selling of people who have already become slaves. In this circumstance, a slave is a property of his master who does not have any protection against the whim of his master. A slave can never own property and can never marry without his master's consent; a slave is a tool to be used and a tool to be discarded when broken; slave could be sold away from his family or witness his children being taken away to disappear forever under an auctioneer's hammer and it is not a crime if a freeman killed a slave.

Slave trade from black Africa to the outside world began with the trade across the Sahara to the Mediterranean world. It began around 9th century and lasted till the end of the 19th century. It was followed by the slave trade across the
Atlantic to the Americans which started towards the end of 15 th century and lasted till the end of the 19th century. In whatever means, or method in which the trade was being carried out, it remains a factor which led to the dispersal of African peoples and their cultures all over the world ${ }^{2}$. According to Awolowo ${ }^{3}$, 'Slave trade laid the foundation of centuries of Africa's spiritual and mental darkness, physical barbarity and human degradation, much darker, more barbarous and more degraded than anything previously known on the continent'. On the whole, the external slave trade depopulated Africa with over 40 million of her able bodied men and women being carried into slavery. Secondly, the slave trade afforded Europe the opportunity to accumulate substantial amount of capital which it used to advance their technology as well as industrial growth. It also pegged down the economic development of Africa and prevented the continent from ranking among the leading industrial zones of the world. In addition, African personality was dehumanized by the slave trade, which marked the beginning of the entrenchment of inferiority complex in Africa. To cap it up, the trade marked the beginning of greater European attention to and participation in the affairs of African continent ${ }^{4}$. In fact, the 
slave trade stained and ruined much of the fabric of African society while permitting nothing better to replace it ${ }^{5}$. It is in view of the enormous problems associated with this obnoxious trade which spanned through several centuries in Africa that this writer joined other Pan-Africanists in calling for reparations as a way of atoning the sins committed by the beneficiaries of the slave trade.

This paper thus seek to address the issue of reparations in any form as a kind of palliative measure to cushion-in the effects of the slave trade. The paper includes the Arab world with the western world as those liable to pay reparations to African continent. The writer supported his call on the fact that the principal industry of Africa for many centuries was the trade in slaves carried on mainly by the Christian peoples of Western Europe and by Muslim Arabs ${ }^{6}$. He also went further by describing slavery and slave trade as the first international investments in capital. It was the first large scale investment that was inter-continental. Many Europeans invested in ships and in the goods and services taken from these African countries and became independently wealthy. He also supported his view by taking a review of slave trade across the Sahara to the Mediterranean and slave trade across the Atlantic. He therefore affirmed that all those who took part in enslaving Africans are responsible to bear the guilt of the heinous crime of slavery.

\section{Slave Trade across the Sahara to the Arab world}

One neglected aspect of slavery and slave trade in Africa is the issue of slave trade across the Sahara to the Mediterranean world or to the Arabian land. The reason for this erroneous neglect is not far-fetched. It was due to a number of reasons which includes the popularity which the Trans-Atlantic slave trade had over the trans-Saharan slave trade and also the abolition of the slave trade which was championed by Europe. These and many more would have given one the impression that slave trade in Africa started and ended with the Europeans. The fact that needs to be established here is that slave trade across the Sahara was truly the origin of the blacks in diaspora.7This is due to the fact that the trade preceded that of Atlantic slave trade and the years of its existence superseded that of the slave trade across the middle passage. Toledano, affirms that descendants of the African slaves brought to the middle East during the slave trade still exists there today and are aware of their African origin ${ }^{8}$.

The slave trade across the Sahara to the Mediterranean world began around $9^{\text {th }}$ Century and ended in the $19^{\text {th }}$ Century. This means that the trade lasted for 1000 years far more than that of Atlantic slave trade which lasted for 400 years. In addition, the number of African slaves exported via the Sahara was equally enormous compared to the numbers exported through the Atlantic. In the estimation of Amuni, over 17 million $^{9}$ of Africans were exported to the Muslim world as a result of the slave trade across the Sahara.
The slave trade across the Sahara is one of the oldest slave trades, predating the European Trans-Atlantic slave trade by 700 years. Male slaves were often employed as servants, soldiers or labourers by their owners while female slaves were long traded to the Middle Eastern countries and kingdoms by Arab and oriental traders as concubines and servants. Arabs, Africans and oriental traders were involved in the capture and transport of slaves northward across the Sahara desert and the Indian ocean region into the middle East, Persia and Indian subcontinent.

Two main routes were distinguishable during this era: Overland routes across the Maghreb and Mashriq deserts which was known as Tran Saharan route and sea routes of East Africa through the red sea and Indian ocean known as Oriental route. Arab traders brought Africans across the Sahara to Maghreb land for onward transportation to Middle East from places like Ghana, Gambia, Mauritania and Hausa land in Nigeria ${ }^{10}$. Arabs also brought Africans across the Indian ocean from present day Kenya, Mozambique, Tanzania, South Sudan, Eritrea, Ethiopia and elsewhere in East Africa to present day Iraq, Iran, Kuwait, Turkey and other parts of the middle East and South Asia mainly Pakistan and India.

Slaves were often bartered for objects of various kinds. In the Sudan, they were exchanged for clothes, trinkets and so on. In the Maghreb, they were swapped for horses. In the desert cities, lengths of cloth, pottery, Venetian glass, slave beads, dye stuffs and jewels were used as payment. Alongside gold coins, cowries from the Indian Ocean or the Atlantic were used as money throughout black Africa.

Enslaved Africans were sold in the towns of the Muslim world. It was reported that pilgrims coming from Tekrur (present day Senegal) had brought 1,700 slaves with them to Mecca in 1416. In North Africa, the main slave markets were in Morocco, Algiers, Tripoli and Cairo where sales were held in public places or in sorks. Potential buyers made a careful examination of the 'merchandise' by checking the state of health of a person who was often standing naked with wrists bound together. ${ }^{11}$

\section{Slave Trade across the Atlantic: An Historical Overview}

The Portuguese were the first among the White race to import slaves from Africa to Portugal in $1444^{12}$. The English merchants entered into competition in a big way against Portugal in slave trade with Africa. The demand for slaves by Europeans grew bigger as more slaves labor was required for Spanish plantations in the Americas and the West Indies. With the intense rate at which this nefarious trade grew thus began 'racism', a monster that still haunts African society.

When the New world was discovered, Spain, Britain, Holland and France began plantations such as tea, plantain, sugar and cotton. They also made effort in mining the mineral deposits in such areas. There was therefore the need to employ people for the plantations. The Europeans 
then made use of Red Indies. They soon discovered that the people could not cope with the work and there was expansion of mining and agricultural production in these new areas. Consequently, there was an ever-growing demand for Black slaves from Africa and before long, European merchants developed an elaborately organized trade, with ships specially constructed for the purpose of regular shipping of slaves from Africa to the slavereceiving territories ${ }^{13}$.

Europeans loaded with goods like metal bars, knives, clothing, hardware, weapons, trinkets among other things and sail to Africa. They exchanged these goods with human cargoes (slaves), Ivory and Gold from Africa. Americans received these 'goods' i.e. slaves from Europeans and exchanged them for goods like tobacco, sugar, cotton, rice, ginger and precious stones.

The conditions of these slaves were worse on the ship. They were treated harshly and exposed to diseases and cold resulting in death of many on board without reaching America. In addition, women among them were subjected to rape by these sailors and slave merchants with no resistance.

Throughout the four hundred years of this trade, it was recorded that there was the transportation of the 'fittest and best ${ }^{14}$ of Africa's sons and daughters across the "middle passage" to the Caribbean and the Americas. In the words of Olaniyan, this transportation no doubt resulted in the depletion of Africa's vibrant population and effectively halted its technological advancement ${ }^{15}$.

This age-long rape on Africa created manifold problems for the Continent of which Africa is yet to recover from. There was therefore the problem created as a result of brutalization and dehumanization of Black Africans. The trade set in motion the cultivation of inferiority complex in the minds of Africans towards the white race. Moreover, there was the neglect and destruction of agriculture and pastoralism together with the killing of initiative for manufacturing leading to majority of Africans living below subsistence level. Above all, the trade paved way for the growth and development of the West and altered the rate at which Africa's development was growing prior to the era of Atlantic slave trade.

\section{Evolution of Reparation Movement in Africa}

Reparation is the idea that some type of compensation should be provided to the descendants of enslaved people both within Africa and in the diaspora, in consideration of the coerced and uncompensated labor their ancestors performed over several centuries ${ }^{16}$. It refers to the process of repairing, healing and restoring back wrongs committed against Africans and people of African descent during several Centuries of slavery and slave trade by Christian Europe and Muslim Arabs. In addition, it involves a compensation sought by a defeated nation for damages done to it in a war. Ajayi rightly described the idea of reparation as a determined mission to return Africans both home and in the diaspora to their rightful position in the interest of a fair, just and equitable international order ${ }^{17}$.

The movement for reparations in Africa began with the meeting of member countries of organization of African Unity (O. A. U) now African Union (A. U) in 1992 where twelve members tagged 'Group of Eminent Persons'(GEP) were sworn-in, to pursue the goal of reparations to Africa. The group comprised twelve illustrious sons and daughters of Africa and African descent. It was headed by Late Chief M. K. O Abiola (the group was drawn from a host of professions and all of them had made a 'mark' in their various chosen professions ${ }^{18}$.

The inauguration of the Group of Eminent Persons (GEP) no doubt, gave birth to the first Pan African conference of 1993 in Abuja, Nigeria. A sum of \$500, 000 was dedicated to this conference which was single-handedly financed by Late Chief M. K. O Abiola. During this conference, an official proclamation was issued. The proclamation referred to the 'moral debt' and the 'debt of compensation' owed to Africa by countries that engaged in slavery, colonialism and neo-colonialism. The proclamation advocated for 'capital transfer and debt cancellation' as well as a re-ordering of international relations to give Africa more representation in the highest decision-making bodies and in particular, a permanent seat on the United Nations Security Council. In addition, demands that the slave trade be named a crime against humanity and that the former slave-trading nations should apologize for engaging in the trade were also made.

In 1999, 'Truth Commission Conference'19 was held in Accra, Ghana. The Conference comprised private individuals from nine African countries, the United States, United Kingdom and three Caribbean countries. The conference came to the conclusion that, the major cause of Africa's problems lies in several years of slavery and colonization of Africa by foreigners. It estimated a total sum of $\$ 777$ Trillion, as the debt owed Africa by foreign invaders, to serve as compensation and in case of nonpayment, Africa's debt should be cancelled.

In $2001^{20}$, another conference which remains the latest move of campaign by African countries and African diaspora, to gain international recognition, for the injustices perpetrated against them in the era of slave trade was held in Durban, South Africa. The conference was officially known as the World Conference against Racism, Racial discrimination, Xenophobia and Intolerance.

During this conference, the issue of reparations generated series of debate among African leaders which further established controversy surrounding the idea of reparations in Africa from the beginning. For instance, former President of Nigeria, Chief Olusegun Obasanjo suggested an apology from states which practiced and benefitted from slavery and slave trade. Also, President Abdoulaye Wade made it clear that demands of monetary compensation to restitute slavery and slave trade trivialized 
the impact of slavery. He therefore suggested a case-bycase approach that would consider the position of the African diaspora. There was also the debate as to how reparation could reasonably be assessed, while some argued for both an apology and reparations from beneficiaries of slavery and slave trade. Others advocated that slavery and slave trade should be declared a crime against humanity and that reparations should not be considered as a 'compassion or charity' but an 'affirmation' of basic 'human rights'. At the end of the debate, the conference issued its declaration acknowledging the arguments that the historical injustices of the slave trade have undeniably contributed to poverty, underdevelopment, marginalization, social exclusion, economic disparities, instability and insecurity in different parts of the world. It therefore recognized the need to take urgent measures for the social and economic development of affected societies and Africans in the diaspora. These would include debt relief, poverty eradication, building or strengthening democratic institutions, promotion of foreign direct investment and market access ${ }^{21}$.

\section{Arguments of Opponents of Reparation}

As should be expected, there were oppositions to the idea of reparation to Africa by Western nations immediately when the renewed campaign for reparation took off in the early 90s. The 'so called' anti-reparations advocates also emerged even from within African continent and this also attests to the controversy which the idea of reparations generated when the movement began.

Anti-reparation advocates have argued that there is need for better understanding of the role of Africans in the era of slave trade. They argued that African merchants determined the assemblage of trade goods accepted in exchange for slaves and this called for a shared responsibility between western nations and Africans for their role in the slave trade.

It was also argued further that, there is no single group that was clearly responsible for the crime of slavery. They supported this argument on the promise that it was Black Africans and Arabs that were responsible for enslaving people of African descent throughout the World ${ }^{22}$.

The condition of African-Americans was also used as a basis against the idea of reparation. They argued that reparations for slavery cannot be justified on the basis that slave descendants are subjectively worse off as a result of slavery, because it has been suggested that they are better off than they would have been in Africa if the slave trade had never happened.

Anti-reparation advocates went further to debunk the claim that only whites have benefited from slavery. They declared the claim as 'false assumption' by arguing that if slave labor had created wealth for America and other slaveowing nations, then, it has created wealth for Black Americans, Black collaborators and Arabs as well.
Furthermore, they argued that historical precedents used to justify reparations claim are not enough justification for payment of reparation to Africa. They used the payments to Jewish survivors of Holocaust and Japanese Americans as examples. They argued that in each case, the recipients of reparations were the direct victims of the injustice or their immediate families. It is therefore difficult to identify the direct victims of slavery or their immediate families in Africa making the payments of reparations not possible and if such payment is being made, it would be the only case of reparations to people who were not immediately affected and whose sole qualification to receive reparations would be racial.

Anti-reparation advocates also argue that there is a very long causal chain between slavery and colonialism and the current situation of Africans. They explained that social movements for human rights are most likely to be successful where there is a short and recognizable connection between cause and effect. They are of the view that the evidence and logic needed to show how the slave trade caused under development in Africa today is detailed and complex. This is so because according to them, slave trade was abolished by the British in 1807 and by the United States in 1808. They went further by saying that, social movements are successful when direct harm can be demonstrated. In retrospect, the direct harms of slavery endured by those enslaved are easy to identify, the direct harm visited upon their descendants is far less clear. With this, it is therefore, difficult to persuade those Western states who might be expected to pay compensation that the often tragic situation of Africans and members of the African diaspora alive today is a consequence in part of the actions of the West's own forbears.

From the home-front however, there were anti-reparation advocates who held contrary opinion to the idea of reparations to Africa. One of such opponents of reparations was Senegal's President Abdoulaye Wade. He argued that the demand for reparations trivialized the impact of slavery by suggesting that it could be compensated with money. He noted that some Africans, including his own ancestors, had owned slaves. He went further that, if reparations were to be paid for slavery, then, he himself might be liable to pay them, as his ancestors had owned thousand of slaves. He, however, found the proposal for monetary compensation for slavery, insulting. According to him, "it is absurd that you could pay up a certain number of dollars and then slavery ceases to exist" ${ }^{, 23}$. He further argued that there was far more racism and xenophobic violence within Africa than against Africans in Europe. According to him, promotion of a better call for reparations is an easy way to deflect attention from internal African Politics, and the many abuses of human rights by African dictators.

The Nobel laureate Professor Wole Soyinka corroborated the view of Abdulaye Wade on the issue of human right abuse by African leaders. Wole Soyinka's argument coincided with the reign of Late Gen. Sani Abacha when the lead proponent of reparation in Africa, Late M. K. O 
Abiola was being detained. According to Wole Soyinka, Abiola is today himself enslaved by one of the new breed of slave dealers, who actually boasts of power over the most heavily populated, most talented slave market that the African world has ever known. According to him, reparations, like charity, should begin at home, and the wealth of the Mobutus, the Babangidas and the Abachas should be utilized as down payment ${ }^{24}$.

\section{Precedents of Reparations as a Justification for Africa's Claims}

It has been observed that Africa's economic marginalization started with the deprivation of its manpower by the slave trade, followed by exploitation and the siphoning of its natural resources occasioned by colonial rule which make Africa to lack the capacity to compete commercially in the world economy. In addition, slave trade has been regarded as the greatest practical evil which has ever afflicted the human race ${ }^{25}$.

Many races apart from Africa had also at one time or the other being a victim of discrimination and intolerance. It is on record that those groups had been adequately redressed for wrongs committed against them in the past. This no doubt necessitated the need for Africa to be compensated as restitution for evil committed against her during the era of slave trade.

One typical example of reparations paid was that of Germany to the state of Israel as a result of the holocaust. The issue of reparations to the Jews for the holocaust resurfaced in international discussion in the 1990s when Jewish groups began to demand that unpaid life insurance policies on victims of the holocaust be paid and that monies deposited by Jews in Swiss banks before and during the Second World War be paid to survivors of murdered Jews. This call however, received wide support from people throughout the world. Consequently, Germany paid several million of dollars to Israel in phases ${ }^{26}$. In view of this, if Israel could be paid restitution for her six million Jews murdered between six to twelve years, then, what is wrong in reparation for Africa for immorality against Africa over a period of several centuries?

In the same token, the growing movement for reparations to Afro-Americans in the U.S was also a great factor to the calls for reparations to Africa. The movements believed that Europe, America and other interests that profited from slave trade owe reparations to blacks. Also, within the United States, the demand for reparations took the form of apology being demanded and sponsored by a Congress man, Tony Hall in 1997. Another form is the movement to bring class action civil law suits against corporations that have allegedly benefitted from the enslavement of Afro-Americans. Consequently, these demands have since yielded results in the United States of America. For instance, on July 30, 2008, the United States House of Representatives passed a resolution apologizing for American slavery and subsequent discriminatory laws. Also, Aetna Inc., a company accused of writing life insurance policies on the lives of enslaved Africans with slave owners as the beneficiaries, issued a public apology thus giving birth to the 'Corporate restitution movement ${ }^{\text {, } 7}$

The United States of America, under the civil liberties Act of 1998, signed into law by President Ronald Reagan, apologized for Japanese-American internment during World War II and provided reparations of \$20,000 for each of the survivors.

With the repeated apologies and reparation received by groups which were subjected to other scourges and injustices, it is then a matter of urgent importance that Africa too deserved reparations which should not be considered as an act of compassion or charity but an affirmation of basic human rights.

\section{Conclusion}

By and large, the advent of slave trade remains epochal in the history of Africa's relations with the outside World and of all phases of human history, the era of slavery remains the most horrible phase of African history. ${ }^{28}$ It was a phenomenon which dealt a debilitating blow on black man's dignity when Africa's able bodied men and women were reduced to articles of trade. It was a situation which laid the foundation of economic imbalance between Africa and the rest of the world, most especially the West. Slave trade afforded the slave trading nations (Europe and Middle East) the opportunity to accumulate substantial amount of capital which they used to advance their technology as well as industrial growth and thus set in motion African's under development. In view of immense problems occasioned by the slave trade, reparations is thus seen as primarily as a way of correcting modern economic imbalance. Such reparation should take the form of cancellation of Africa's debt as part of the restitution due for centuries of slavery of Africans because slave-holder nations have unjustly enriched themselves at expense of those that they enslaved. In addition, reparations should take the form of 'capital transfer' to Africa to speed up her technological development.

In the campaign for reparations for Africa, the case should now be channeled through international political and moral debate. African Union (A.U) should take up the idea of reparations as a focus of its activities. African reparation movement should be revived and the groups must work together rather than championing the course of reparation individually.

\section{References}

[1] J.E. Inikori, "Origin of the Diaspora: The slave trade from Africa", in Tarikh, Vol. 5, No. 4, 1978. P. 2

[2] Ibid. 2 
[3] O. Awolowo, The problems of Africa: The need for ideological re-appraisal, London and Basingstoke, Macmillan, 1977.p. 20

[4] Ibid. 20

[5] J.C. Anene, "Slavery and Slave trade" in J.C. Anene and G.N. Brown (eds.) Africa in the 19th and 20th Centuries, Ibadan: Ibadan University Press, 1981 pp. 92-109.

[6] Ibid

[7] J.E. Inikori, Origin of the diaspora: The slave trade from Africa...., p. 2

[8] E.R. Toledano, "Representing the slave's body in Ottoman society' In Thomas Wiedeman and Jane Gardner (eds.) Slavery and abolition in Journal of Slave Studies, vol. 23, No. 2, 2002. pp 57-64. See also "Arab slave trade" http.//en.wikipedia.org/wiki. Retrieved 29 July, 2011.

[9] O.K. Amuni, 'Arab enslavement of Africans: The reparation Caravan must reach Arabia and the Middle East', in the Special Issue of Journal of CBAAC, 2009, 119.

[10] Arab slave trade, http://enwikipedia.org/wiki op cit. Retrieved 29 July, 2011

[11] J.O Humwick, 'Black Africans in the Islamic world' In Tarikh, vol.5, No.4, 1978.pp. 20-40. See also 'Arab slave trade'. http://en.wikipedia...

[12] O. Awolowo, The problems of Africa: The need for ideological re-appraisal...', p.21

[13] J.C Anene, 'Slavery and slave trade'... pp.92-109

[14] A.O Olaniyan, 'Standing History on its head: Deconstructing Africa's encounter with the fourth epoch' in the Special Issue of the Journal of CBAAC, 2009. p. 44

[15] Ibid. 46

[16] A. Banjo, 'The rise of global Africa and the question of reparations' in the Special Issue of Journal of CBAAC,
2009, pp 509-528. See also 'Reparations for slavery', http://en.wikipedia/wiki. Retrieved 29 July, 2013.

[17] J.F Ade Ajayi, 'Towards African Renaissance in the TwentyFirst Century' in Journal of CBAAC. 2001, pp 63-64. See also Jide Owoeye 'Understanding the reparations movement' in Nigerian Tribune Newspapers, July 31, 1992, p.5.

[18] For full details on Group of Eminent persons, see A. Banjo, 'The rise of global Africa and the question of reparations', in the Special Issue of the Journal of CBAAC, pp.509- 528

[19] 'Reparations to Africa and the Group of Eminent persons', http://en.wikipedia/wiki', Retrieved on $29^{\text {th }}$ July, 2013

[20] Ibid

[21] See The punch newspapers, June 17,2010 .p. 7

[22] 'Reparations for slavery' http://en.wikipedia/wiki. Retrieved on 29th July, 2013. See also Egbamuno, 'Europe won't pay reparations' in New Nigerian Newspapers, May 6,1991 .p. 1

[23] See Africa Recovery, vol.15, No.3, October 2001 .p.8

[24] Ibid

[25] O. Awolowo, 'The problems of Africa: The need for ideological re-appraisal'.... p.22

[26] A. Banjo, 'The rise of global Africa and the question of reparations,' in the Special Issue of Journal of CBAAC, 2009 op.cit .p. 514. See 'Reparations to Africa and the Group of Eminent persons'. Retrieved 29 July, 2013

[27] 'Reparations to Africa and the Group of Eminent Persons' http://en.wikipedia/wiki. Retrieved 29 July, 2013

[28] O. Ugwuanyi, 'The future of a neglected past: slavery, slave narrative and Africa's project of self-knowledge:' in the Special Issue of Journal of CBAAC, 2009,p.85 